\title{
Pancreatic Beta Cell Adenoma
}

National Cancer Institute

\section{Source}

National Cancer Institute. Pancreatic Beta Cell Adenoma. NCI Thesaurus. Code C67457.

An adenoma arising from the beta cells of the pancreas. It produces insulin. 